\title{
A Lesson Of Lost Political Capital In Public Higher Education: Leadership Challenges In A Time Of Needed Organizational Change
}

\author{
Mark Hilton, Lyndon State College, USA
}

Rod Jacobson, Lyndon State College, USA

\begin{abstract}
All higher education institutions are struggling with a rapidly changing market and financial landscape. Here is a management-centered analysis of what happened when a college president, recognizing the need to make a radical adaptation to those changes, tried moving a campus community to a new organizational model, without collegial consensus, and too quickly. The result was that the president lost political capital and the college underwent a change in leadership. Yet the need for a new management model still remains.
\end{abstract}

Keywords: College Presidents; Educational Political Capital; Educational Budgets

\section{INTRODUCTION}

the conclusion of a 13 year tenure, the president's numerous accomplishments in the best interest of
the institution, of its students, and of the local rural community which the college serves in a variety
of vital ways were readily acknowledged by many of the long-term professors and staff. The college, at the end of this president's tenure, was a significantly better place: she had refurbished existing facilities; she had secured funds to build new dormitories, academic, administrative and student recreational spaces, athletic facilities, and parking lots; she had added new (successful) programs reflecting a changing education market place; and she had grown the college endowment from $\$ 250$ thousand to over $\$ 3$ million.

The president had arrived on campus 13 years earlier saddled with an operating budget deficit. Those early years, however, were still the almost halcyon days of college administration (to be sure, colleges in her state system were never adequately funded by the legislature). Nevertheless, she was able to identify and analyze various options to reduce the deficit and implement the most workable option (which necessarily included painful human resource reductions). New presidents always enter office with a reserve of good will and political capital. Needless to say, hers, during this first tough year in office, took a major hit from which, in some quarters, she never recovered.

But given the president's unusual length of tenure and efforts at an open style with a consensus-based approach, the relationship with the faculty and staff did improve noticeably over time. While admitting that the president had made significant contributions to the institution and the community, however, the faculty and staff would also acknowledge that the final 18 months of her college presidency were very difficult, and that tensions that had subsided over time had resurfaced, largely over a looming budget deficit and no universally satisfactory way to reduce it. A small minority of the faculty, focused less on the larger economic issues than on idealistic ones specific to their own status, remained difficult and obstructive.

Worsening budget constraints, more or less coinciding with worsening economic conditions in American society generally, led the state legislature to reduce state appropriations. The president's college was, to all intents and purposes, operating solely on revenue from tuition, room and board. This in turn set off a mood of long-range 
uncertainty which only exacerbated the deficit problem. The president's college, one of five (a technical, a community, and three geographically dispersed 4-year state colleges all with a single board of trustees and a single chancellor), is provided a few services common to all the schools but is required to operate independently with a balanced budget. Operating budgets are typically prepared for each new academic year and for only that single year.

\section{CHRONOLOGY OF EVENTS}

What follows is the rapid time sequence within which the president's plan for a change of her operating model occurred and the pattern of key events that led her to retire sooner than originally planned.

\section{January 2010}

Because of greater than usual predicted revenue shortfalls, the Board of Trustees of the five-college system required each college to develop two variants (best case and worst case) of their three-year budget projections based on tuition rate increases for the system as a whole. In every case, the balanced, practical, and conservative projections showed costs growing more rapidly than revenue. The projected operating budget at this president's college uncovered a potential million plus dollar deficit in years 2 and 3 under current operating procedures as a result of existing commitments to faculty contracts, benefits, and retiree costs, all of which were outpacing revenue. In addition, another round of reduced state appropriations, all but negligible all along anyway, worsened the problem, and the prevailing mood.

\section{May 2011}

The Board of Trustees set the FY 2011 tuition rate increase at 4\%, with a warning of minimal increases going forward. In effect, the college could not look to tuition increases as a way to solve its budget issues.

\section{June 2010}

Institutionally-sponsored research and analysis indicates that circumstances require an aggressive attack plan necessarily and inevitably including reductions in programs and personnel.

\section{July 2010}

An admissions recruitment disaster looms: early registration data shows a tuition shortfall of 80 students. The Dean of Admissions leaves the college.

\section{October 2010}

NEASC (New England Association of Schools \& Colleges) re-accreditation process site visit, stressful at any time, was especially stressful this cycle as different elements of the college community sought to represent the college atmosphere and mood in accordance with the nature of their relationship to the administration. The college administration develops a plan to offer an invitation, with incentives, to senior faculty members to retire. A minority of angered faculty enlists students and the local press in its protests, and a public relations disaster follows.

\section{April 2011}

NEASC accreditation is renewed with recommendations that the work on the administration's costreduction plan be continued and, moreover, that these cost-containment steps be concluded within two years. The NEASC report and recommendations confirm the president's fears and empower her to press forward in the execution of cost cutting measures to go into effect April $15^{\text {th }}$.

More resistance from the faculty continues, resulting in more bad press and public relations. The college faculty by-pass the president and request directly from the chancellor a delay in layoffs and ask for time to study the college's financial situation and to come up with solutions. A number of faculty members, supported by students, 
express vocally that they are disturbed by suggestions to cut low-enrollment (i.e., non-self-supporting) courses. Faculty point out that enrollment numbers alone do not justify cutting courses that serve as pre-requisites or essential core background for certain majors - often for majors based in entirely different departments.

The chancellor steps in, orders a pull-back on the president's plan and approves a fresh look at her budget proposal - in effect, the April $15^{\text {th }}$ plan is put on hold. The president announces retirement and delay of budget/layoffs.

\title{
May 2011
}

The final FY 2012 budget is due at the chancellor's office. The chancellor responds to the faculty's request for time to study the situation: The president's full layoff plan will not be implemented, and faculty and staff are given until November 1, 2011, to find cost-savings solutions.

Faculty and staff begin a summer-long process of "brain storming" in performance- and financials-focused groups centered on the following areas:

\author{
Efficiency \\ Curriculum \\ Cost Containment \\ Admission/Recruitment \\ Vision \& Mission
}

But these sessions (authors' opinion) worked without clear leadership and responsibility that has to date delivered minimal results at best.

\section{July 2011}

The chancellor appoints an interim president to a one-year post while a full-time presidential search begins.

\section{CONCLUSIONS}

The college community was inadequately informed of, and inadequately prepared for, the changes and turmoil that took place in so short a time span.

The authors of this article spent many years in private industry and believe strongly that all organizations require effective leadership and management to thrive. While this college's president displayed much positive strength as a leader - good vision, mission, strategic and tactical direction - the organization and system as a whole could simply not absorb, nor support, the rate of change being forced upon it. The faculty, staff, and administration at this public college sought first to preserve jobs and course offerings as their primary focus, and then secondly to address unsustainable programs, courses, delivery models, and other challenges impacting efficiency and effectiveness. Many faculty and staff members still believe that the college's cost problems are an Admissions Department problem and not one requiring a major long-term model shift that involves the entire college community in questioning everything it does.

\section{The challenges to higher education have not gone away.}

Many articles point out that the traditional four-year college, while still considered the educational ideal, was established for the fortunate few and not the majority. But colleges and universities are no longer rare institutions serving a rare subset of society. Higher education today has grown to serve a very large and diverse socio-economic segment of our society. And we in public higher education cannot continue to ignore the long-term sustainability challenges we face as institutions, and we must, rather, begin to take a critical look at what services we deliver and how we deliver them. Federal and state governments will continue to struggle with mounting budget deficits and uncertainty going forward. Findings suggest that public higher education institutions should not expect 
state and federal funding to return to the levels we have experienced in the past. Continued pressure at the federal, state, and trustee levels aimed at limiting approval of annual tuition increases (if any) in public higher education will increase the fiscal challenges of balancing the budget.

In addition, segments of the public and of the constituents our colleges serve have begun to question the value of the traditional four-year college education relative to the degree-earners' return on investment in an uncertain job market. Many students today are graduating with substantial debt and limited job prospects given the current economic conditions. As a result, the customer is crying out for lower-cost alternatives that will support employment prospects and other opportunities for advancement.

\section{Leadership must still make the hard decisions.}

The authors believe that at our institution we have missed the opportunity to take corrective action to begin positioning this public college for the future. This happened because leadership recognized the nature and size of the problem too late, and reacted too hastily, and, as we stated above, without the faculty's consent. There is still waste, duplication, and inefficiency across the organization we describe here despite the summer-long faculty and staff committee work to root it all out. Yet these inadequacies must be identified and ultimately eliminated. We still have a conservatively projected deficit looking forward over the next two years. Unsustainable programs and curriculum must be questioned, upgraded, or eliminated. New programs, modifications to existing programs, new service delivery models and options must be defined and implemented to meet the needs of the students we serve and the communities we support.

\section{This may also mean reductions in our current work force.}

If we (faculty, staff, and administration) are unable to identify cost-effective and efficient solutions to our current challenges, the new president's decisions may be even more daunting and painful to the organization. Job preservation will most certainly not be the new president's main focus.

We can conclude that our college leadership, administration, faculty, and staff must begin thinking about the operation of our institution as a business. Products and services must meet customer needs and requirements in an effective and efficient manner. We must question all "sacred cow" programs, courses, delivery models, and content from the standpoint of enrollment and sustainability. Like any business, we must understand our cost drivers and ensure we have a revenue stream that supports our expenses, ongoing maintenance, and investment. We are, after all, a service-based public organization that must execute the college's mission: Prepare every student for personal and professional success through experience-based high quality programs in the liberal arts and professional studies.

Our concluding questions: how much political capital will need to be expended by our next full time president? We are losing critical time to address these issues while the search for the new president continues. Are we losing a critical opportunity (as a college community) with our interim college president to begin to identify and make the hard choices which inevitably will need to be made by the next president?

\section{AUTHOR INFORMATION}

Mark Hilton is a corporate consultant. In addition to consulting with clients across North America, he is Professor of Business at Lyndon State College in Lyndonville, VT. Hilton is a former aerospace industry vice president. Two companies he founded were subsequently acquired. A Lyndon State graduate, Hilton earned his MBA from Plymouth State University in New Hampshire. E-mail: mark.hilton@lyndonstate.edu. Corresponding author.

Rod Jacobson is currently an assistant professor and chair of the business department at Lyndon State College in Lyndonville Vermont. Prior to joining Lyndon, Jacobson's former career included working for five fortune 500 technology companies and also spent time working for the Ocean Spray cooperative headquarters in Massachusetts in their marketing information center. Jacobson's business career accomplishments working across all business functions as a senior level manager and leader primarily covered planning, consulting, business operations and 
information technology and information management. Known as a star performer, Jacobson took early retirement in 2005 from Hewlett Packard to pursue his second and best career - teaching undergraduate business students. A Northeastern University graduate, Jacobson earned his MBA from Babson College in Wellesley Massachusetts. E-mail: rod.jacobson@Lyndonstate.edu. Corresponding author.

\section{BIBLIOGRAPHY}

1. Jeff Selingo. Where Will Innovation Begin? The Chronicle of Higher Education retrieved October 20, 2011 from http://chronicle.com.

2. David J. Staley, and Dennis A. Trinkle. The Changing Landscape of Higher Education Retrieved January/February 2011 from EDUCAUSEreview.

3. George L. Mehaffy. Educational Transformation in Perilous Times: Navigating our Way to the $21^{\text {st }}$ Century Part II. Delivered at our college on October 7, 2011.

4. Lynn O'Shaughnessy. The College Solution: 25 Ways for Colleges to Cut Costs. U.S. News \& World Report retrieved December 28, 2010 from http://www.usnews.com.

5. Kevin Carey. The Mayo Clinic of Higher ED: Has Minnesota Found The Cure For Spiraling College Costs? Washington Monthly retrieved September/October 2010.

6. Geoff Gloeckler. For Leaders, Colleges Turn to Business: Universities are hiring experienced corporate managers to cope with schools growing size, complexity - and funding difficulties. Retrieved August 3, 2008 from Bloomberg Businessweek from http://www.businessweek.com. 
NOTES 